\title{
RADIOCARBON RESERVOIR AGES FROM FRESHWATER LAKES, SOUTH GEORGIA, SUB-ANTARCTIC: MODERN ANALOGUES FROM PARTICULATE ORGANIC MATTER AND SURFACE SEDIMENTS
}

\author{
Steven G Moreton ${ }^{1} \cdot$ Gunhild C Rosqvist $^{2} \bullet$ Sarah J Davies $^{3} \bullet$ Michael J Bentley ${ }^{4}$ \\ ABSTRACT. Lake sediments have the potential to preserve proxy records of past climate change. Organic material suitable \\ for radiocarbon dating often provides age control of such proxy records. Six shallow freshwater lakes on the sub-Antarctic \\ island of South Georgia were investigated for carbon reservoir effects that may influence age-depth profiles from lake sediment \\ records in this important region. Paired samples of particulate organic matter (POM) from the water column and surface sed- \\ iment (bulk organic carbon) were analyzed by accelerator mass spectrometry ${ }^{14} \mathrm{C}$. POM in 4 lakes was found to be in equilibrium \\ with the atmosphere $\left(\sim 107 \%\right.$ modern), whereas 2 lakes showed significant depletion of ${ }^{14} \mathrm{C}$. In each lake, the surface sediment \\ ages were older than the paired POM age. Surface sediment ages showed a much greater range of ages compared to the equiv- \\ alent POM ages, even for lakes located in close proximity. We conclude that sediment disturbance during coring, bioturbation, \\ and periodic resuspension of sediments are likely factors causing the difference in the apparent age of surface sediments.
}

\section{INTRODUCTION}

Radiocarbon dating is a useful tool for providing a chronological framework for Late PleistoceneHolocene paleoenvironmental studies. However, the application of ${ }^{14} \mathrm{C}$ dating to Antarctic sediments is complicated by the difficulty of establishing the temporal and spatial variability of the carbon reservoir effect in that region. Gordon and Harkness (1992) produced an invaluable review and summary of Antarctic marine reservoir corrections, but as yet, no equivalent review exists for Antarctic freshwater environments. Many studies of sediments from freshwater lakes in Antarctica have yielded older than expected ${ }^{14} \mathrm{C}$ ages (Zale and Karlén 1989; Björck et al. 1991a; Ingólfsson et al. 1992; Hjort et al. 1997; Doran et al. 1999; Takahashi et al. 1999; Hall and Henderson 2001). Explanations for the "old" ages depend on sample type and lake location, although the erroneous ages are most commonly attributed to the input of ${ }^{14} \mathrm{C}$-depleted glacial meltwater, contamination by marine water or marine sediment, restricted gaseous exchange due to ice cover, and disturbance of sediments by ice. Other factors that may influence the apparent age of core top sediments are mixing of sediment due to bioturbation, resuspension of sediments by wind-driven circulation, and possible loss of surface material during core recovery.

None of the previous investigations of lake sediments from South Georgia produced ${ }^{14} \mathrm{C}$ ages for lake water, microbial mats, water-borne particulate organic matter (POM), or surface sediments. Ages from core-top sediments were not reported due to disturbance of the poorly consolidated upper sediment during core recovery or due to insufficient carbon for radiometric dating (Birnie 1990; Rosqvist et al. 1999; Rosqvist and Schuber 2003). The aim of our study is, therefore, to provide an estimate of the potential local carbon reservoir effect influencing age determinations on lake sediments from South Georgia.

Here, we report contemporary ${ }^{14} \mathrm{C}$ ages from POM and surface sediments from 6 freshwater lakes on South Georgia ahead of a more detailed chronology and multi-disciplinary paleoenvironmental

\footnotetext{
${ }^{1}$ NERC Radiocarbon Laboratory, Scottish Enterprise Technology Park, East Kilbride, G75 0QF, United Kingdom. Corresponding author. Email: S.Moreton@nercrcl.gla.ac.uk.

${ }^{2}$ Department of Physical Geography, Stockholm University, S-106 91 Stockholm, Sweden.

${ }^{3}$ Institute of Geography and Earth Sciences, University of Wales Aberystwyth, Llandinam Building, Aberystwyth, SY23 3DB, United Kingdom.

${ }^{4}$ Department of Geography, University of Durham, Science Site, South Road, Durham, DH1 3LE, United Kingdom.
}

(C) 2004 by the Arizona Board of Regents on behalf of the University of Arizona Proceedings of the 18th International Radiocarbon Conference, edited by N Beavan Athfield and R J Sparks RADIOCARBON, Vol 46, Nr 2, 2004, p 621-626 
investigation of sediment cores recovered from those lakes. All samples were collected in the austral summer 2002-2003.

The sub-Antarctic island of South Georgia is ideally situated to investigate the chronology of climate change as it lies between the current maximum extent of winter sea ice and the Antarctic Convergence Zone, where warm temperate and cold Antarctic waters meet (Figure 1). Climatically induced changes in the position of these boundaries profoundly impact the environment and are recorded in the sediment by proxy signals (e.g. diatom and pollen assemblage, oxygen isotopes of biogenic silica, carbon and nitrogen isotope ratios of the organic material, and physical parameters, such as grey-scale density, grain size, and magnetic susceptibility). Recent paleolimnological evidence from South Georgia indicates that substantial parts of the island were ice-free by 18,600 calendar BP (Rosqvist et al. 1999), strongly suggesting that deglaciation commenced there much earlier than had been previously thought. Many paleoenvironmental records from other Antarctic and sub-Antarctic islands do not extend beyond the Holocene (e.g. Wasell and Håkansson 1992; Björck et al. 1991a, 1991b, 1996; Jones et al. 2000), which emphasizes the importance of South Georgia in providing long terrestrial paleoclimatic records for the Antarctic region.

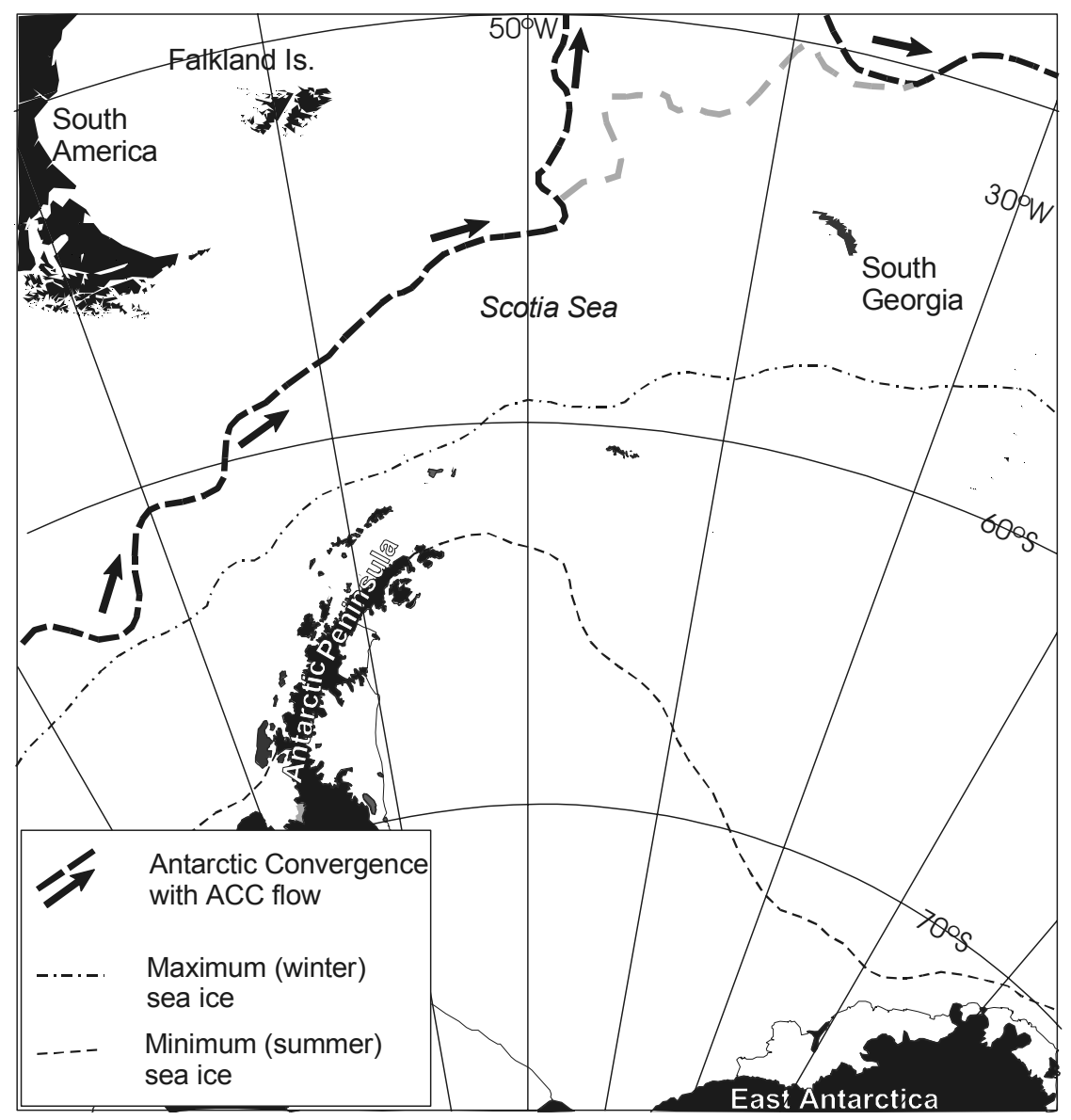

Figure 1 South Atlantic sector of the Southern Ocean showing current positions of the Antarctic Convergence and sea-ice limits. Migrations of these boundaries in response to climatic changes profoundly affect the environment and glacier extent on sub-Antarctic islands. 


\section{Site Locations}

Six freshwater lakes in a range of geographical and topographical settings on the relatively ice-free eastern side of the island were sampled as part of a sediment coring program which aims to investigate the timing and spatial continuity of the glacier retreat after the Last Glacial Maximum (LGM) and the paleoenvironmental history of South Georgia since the LGM (Figure 2). All lakes are small with surface areas between $3000 \mathrm{~m}^{2}$ and $60,000 \mathrm{~m}^{2}$ and a maximum depth of $6.0 \mathrm{~m}$. The presence of overflow channels and low embankments around one or more sides of each lake means that the lakes were close to, or at, their maximum depth at the time of sample collection. In situ roots of terrestrial plants were not observed in recovered sediment cores, indicating that the lakes have not been prone to prolonged desiccation. The lakes are ice-covered for 4-5 months per year but thoroughly mixed when ice-free. Restricted gaseous exchange is not thought to be a major problem for causing ${ }^{14} \mathrm{CO}_{2}$ disequilibrium. Salinity, temperature, and $\mathrm{pH}$ profiles indicate that at the time of sampling, all of the lakes were thoroughly mixed (S Davies, unpublished data). Only 1 lake, Block Lake (BLC), is fed by glacial meltwater and receives substantial inputs of mineral material. The steep gradient and length $(\sim 1.5 \mathrm{~km})$ of the meltwater stream flowing into Block Lake is sufficient to allow thorough mixing of the water and ${ }^{14} \mathrm{CO}_{2}$ equilibration with the atmosphere (Stuiver et al. 1981). Because all of the POM samples consist of primary or secondary productivity, we expected ${ }^{14} \mathrm{C}$ concentrations close to modern atmospheric ${ }^{14} \mathrm{CO}_{2}$ levels.

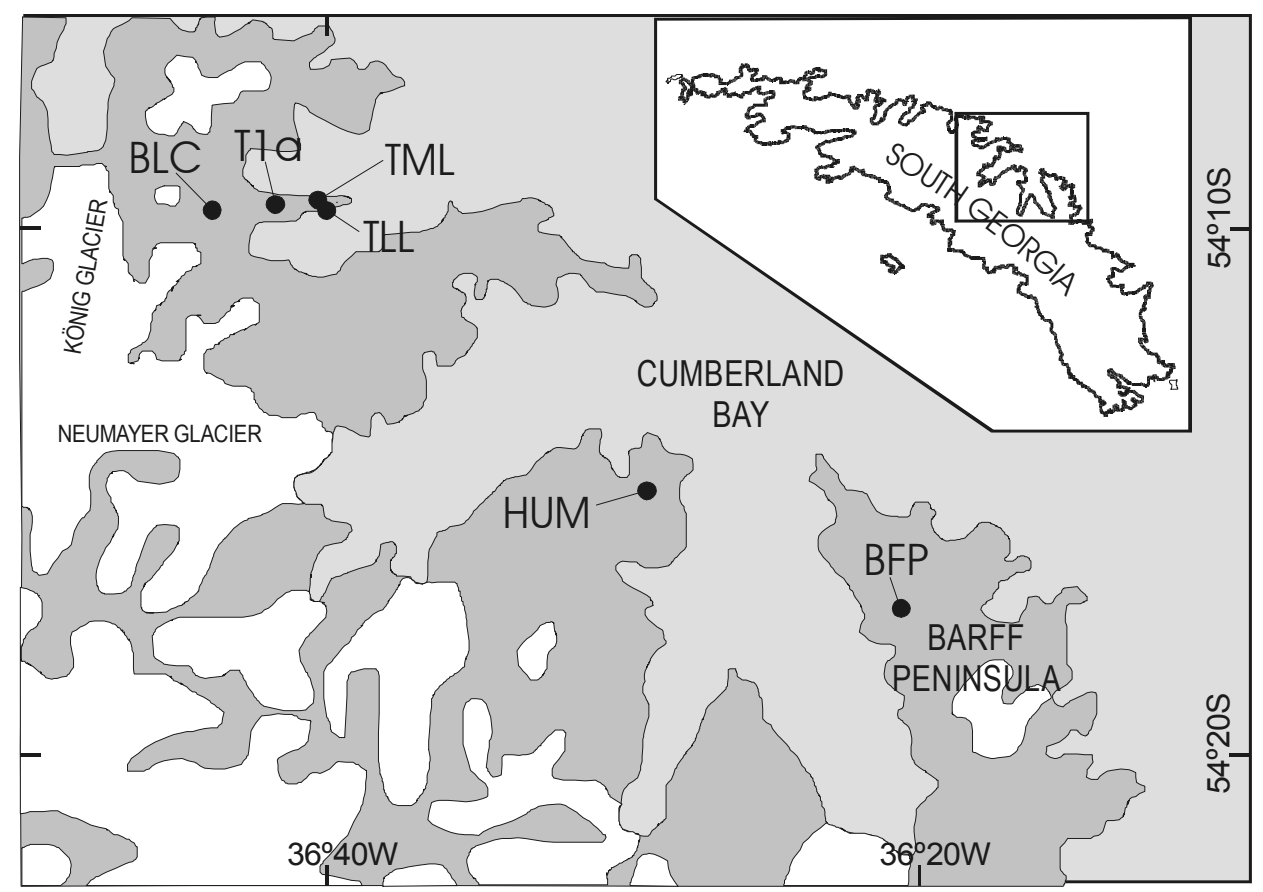

Figure 2 Map showing the location of the 6 freshwater lakes sampled for this study. There is no discernible spatial trend in the ages of either the POM or surface sediments in these lakes.

Most lake names presented are unofficial names and the following codes have been used for brevity: Tønsberg Lake T1 (T1a), Tønsberg Middle Lake (TML), Tønsberg Lower Lake (TLL), Block Lake (BLC), Barff Peninsula Lake (BFP), Humic Lake (HUM). 


\section{Sample Collection}

The POM was collected from the water column by trawling with a hand-held $30-\mu \mathrm{m}$ mesh plankton net. Most of the organic material collected was zooplankton, with lesser amounts of phytoplankton, aquatic insects, and insect larvae.

Samples of the uppermost $1 \mathrm{~cm}$ of sediment were sampled to compare with the ages of core-top sediment (which will be analyzed in the near future). The poorly consolidated nature of the sediment leads to suspicions that some core-top material might be lost during core recovery and direct comparison between surface sediment and core-top ages will allow the amount of sediment lost to be quantified. A plastic scoop on a $1.5-\mathrm{m}$ pole was used to collect the surface sediment. Direct observation of the sampling operation in clear water ensured that only the topmost $1 \mathrm{~cm}$ of sediment was sampled. One lake (TML) was too deep for this method and a core-top sample from a "mini Kullenberg corer" was dated instead.

Particulate organic matter samples were acid washed in $1 \mathrm{M} \mathrm{HCl}$ for $2 \mathrm{hr}$ at $80^{\circ} \mathrm{C}$, surface sediment samples were acid washed in $2 \mathrm{M} \mathrm{HCl}$ for $2 \mathrm{hr}$ at $80^{\circ} \mathrm{C}$. All samples were rinsed free from mineral acid with de-ionized water, dried, and homogenized. The total organic carbon in a known weight of pretreated sample was recovered as $\mathrm{CO}_{2}$ by heating with $\mathrm{CuO}$ in a sealed quartz tube. The $\mathrm{CO}_{2}$ was converted to graphite by stepped Fe/Zn reduction. Sample pretreatment was completed at the Natural Environment Research Council Radiocarbon Laboratory, East Kilbride, UK. Graphite targets were analyzed at the Scottish Universities Environmental Research Centre (SUERC) accelerator mass spectrometry facility, East Kilbride, UK.

\section{RESULTS AND DISCUSSION}

\section{Particulate Organic Matter}

Four of the 6 POM samples (TML, TLL, BFP, HUM) show ${ }^{14} \mathrm{C}$ enrichment of $>100 \%$ modern (106.71-109.04 absolute percent modern carbon [pMC]; Table 1). The ${ }^{14} \mathrm{C}$ enrichment values for these 4 lakes lie close to a current (2002-2003) atmospheric ${ }^{14} \mathrm{C}$ concentration of $\sim 107 \mathrm{pMC}$, extrapolated from the Northern Hemisphere atmospheric ${ }^{14} \mathrm{CO}_{2}$ trend of Levin and Kromer (1997). This indicates that the dissolved ${ }^{14} \mathrm{CO}_{2}$ in these lakes is in equilibrium with the atmosphere and there is no carbon reservoir effect influencing the age of the autochthonous sediments in these 4 lakes.

Two lakes (T1a and BLC) produced POM ${ }^{14} \mathrm{C}$ values $<100 \mathrm{pMC}$, indicating that the lake water is not in equilibrium with the atmosphere. In order to acquire a conventional ${ }^{14} \mathrm{C}$ age, the POM must be diluted with enough "old" carbon to swamp the enriched atmospheric ${ }^{14} \mathrm{CO}_{2}$ signal. With the limited data currently available, it is not possible to definitively calculate the magnitude of the reservoir age for these lakes. However, based on the POM pMC values of $96.60 \pm 0.47$ (T1a) and $93.76 \pm 36$ (BLC), we estimate the age offset to be approximately $\sim 850$ and $\sim 1100{ }^{14} \mathrm{C}$ yr too old, respectively. It is not known at this stage what is producing these age offsets, nor whether the offset has remained constant over time. Hardwater error has been discounted, as the Cumberland Bay region comprises mainly quartzose greywackes, volcanic greywackes, slates, and igneous intrusions in which calcite is absent or present at very low quantities (Skidmore 1972). Contamination by marine water can also be ruled out as the lakes are fresh, conductivity in each is $<100 \mathrm{us} \mathrm{cm}^{-1}$ (S Davies, unpublished data), and analyses of $\delta^{18} \mathrm{O}$ and $\delta \mathrm{D}$ of the lake and through flow water indicate the lakes are replenished by local precipitation, and isotopic enrichment due to evaporation is insignificant (Rosqvist et al. 1999; unpublished data). Relict ${ }^{14} \mathrm{CO}_{2}$ in glacial meltwater has been discounted for the reasons outlined above. At this stage, not enough is known about the hydrology of South Georgia to be able 
Table $1{ }^{14} \mathrm{C}$ concentrations and conventional ${ }^{14} \mathrm{C}$ ages for POM and surface sediment in 6 freshwater lakes, South Georgia, sub-Antarctic.

\begin{tabular}{|c|c|c|c|c|c|}
\hline $\begin{array}{l}\text { Publication } \\
\text { Code }\end{array}$ & $\begin{array}{l}\text { Lake } \\
\text { code }\end{array}$ & $\begin{array}{l}\text { Absolute } \\
\% \text { modern } \pm 1 \sigma\end{array}$ & $\begin{array}{l}\text { Conventional }{ }^{14} \mathrm{C} \text { age } \\
(\mathrm{BP} \pm 1 \sigma)\end{array}$ & $\begin{array}{l}\delta^{13} \mathrm{C}_{\mathrm{PDB}} \% 0 \\
\pm 0.1 \sigma\end{array}$ & $\begin{array}{l}\text { Carbon content } \\
\text { (\% by wt) }\end{array}$ \\
\hline \multicolumn{6}{|c|}{ Particulate Organic Matter } \\
\hline SUERC-592 & T1a & $96.60 \pm 0.47$ & $226 \pm 39$ & -30.1 & 27.3 \\
\hline SUERC-593 & TML & $109.05 \pm 0.49$ & $>$ modern & -27.1 & 65.2 \\
\hline SUERC-594 & TLL & $106.64 \pm 0.33$ & $>$ modern & -28.4 & 59.2 \\
\hline SUERC-595 & BLC & $93.76 \pm 0.36$ & $466 \pm 30$ & -23.7 & 29.4 \\
\hline SUERC-596 & BFP & $108.30 \pm 0.38$ & $>$ modern & -25.7 & 21.6 \\
\hline SUERC-597 & HUM & $107.66 \pm 0.40$ & $>$ modern & -23.7 & 54.0 \\
\hline \multicolumn{6}{|c|}{ Surface Sediment } \\
\hline SUERC-598 & T1a & $85.62 \pm 0.27$ & $1196 \pm 26$ & -22.5 & 14.4 \\
\hline SUERC-603 & TML & $83.42 \pm 0.52$ & $1405 \pm 50^{\mathrm{a}}$ & -25.5 & 28.2 \\
\hline SUERC-600 & TLL & $105.37 \pm 0.70$ & $>$ modern & -25.7 & 34.4 \\
\hline - & $\mathrm{BLC}^{\mathrm{b}}$ & - & - & - & - \\
\hline SUERC-604 & BFP & $94.34 \pm 0.84$ & $417 \pm 71$ & -20.6 & 13.3 \\
\hline SUERC-605 & HUM & $96.63 \pm 0.50$ & $224 \pm 41$ & -27.7 & 39.2 \\
\hline
\end{tabular}

${ }^{\mathrm{a}}$ Core top sample.

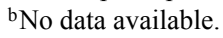

to establish whether groundwater might play a part in introducing ${ }^{14} \mathrm{C}$-depleted water in to the lakes. One possible source of old ${ }^{14} \mathrm{C}$ in the POM samples is resuspended sediment. We consider this to be the most likely source given the poorly consolidated nature of the sediments and the shallowness of these lakes.

\section{Surface Sediments}

In all lakes, the pMC is greater in the POM than in the surface sediment. However, there was considerable variation in the surface sediment ages between lakes. The 2 lakes in closest proximity to each other (TML and TLL) showed the greatest difference in surface age. One possible cause of this discrepancy might be the need to use a core-top sample from TML rather than directly sampled surface sediment. The sediments in all the lakes are poorly consolidated and the deployment of the trigger operated "mini Kullenberg corer" in TML might have been sufficient to dislodge the uppermost sediment, leaving an incomplete sediment record. Further investigation of down-core ${ }^{14} \mathrm{C}$ and ${ }^{210} \mathrm{~Pb}$ profiles will help to clarify this issue. The apparent older surface sediment ages in the other lakes is most likely due to a combination of bioturbation and periodic resuspension and settling of sediment.

\section{CONCLUSIONS}

For the majority of lakes studied, POM in the water column is in equilibrium with the atmosphere, indicating that no carbon reservoir effect influences the age of these autochthonous sediments. However, 2 lakes (T1a and BLC) yield reservoir ages. Therefore, the previous chronology produced for sediments from Tønsberg Lake T1 (Rosqvist et al. 1999) might have over estimated the age of deglaciation by about $850{ }^{14} \mathrm{C} \mathrm{yr}$, assuming that present-day conditions also existed in the past, as no carbon reservoir/dilution effect was taken into account when producing the age model. Likewise, the age model used in the Block Lake record showing millennial-scale climate change (Rosqvist and Schuber 2003) might also need correction by about $1100{ }^{14} \mathrm{C}$ yr. 
We have shown that surface sediment ages are highly variable, even from lakes in close proximity. Therefore, studies of modern analogues from POM and surface sediments are necessary before presenting climate change chronologies based on ${ }^{14} \mathrm{C}$ results. The choice of coring method is critical to obtain an undisturbed sediment-water interface of unconsolidated surface sediments.

\section{ACKNOWLEDGEMENTS}

We thank the main sponsors of the SCOTIA Centenary Antarctic Expedition (2002-2003) to South Georgia: The Royal Scottish Geographical Society, The Carnegie Trust for the Universities of Scotland, The National Geographic Society, the Royal Swedish Academy of Sciences, The Binks Trust, The Brownington Foundation, and The Government of South Georgia and the South Sandwich Islands. We also gratefully acknowledge the help of numerous individuals, including those in the British Antarctic Survey and the captains and crews of HMS Endurance and Ocean Tramp and all the participants of the SCOTIA Centenary Antarctic Expedition. The ${ }^{14} \mathrm{C}$ dating was funded by the Natural Environment Research Council (allocation number 14.45).

\section{REFERENCES}

Birnie J. 1990. Holocene environmental change in South Georgia: evidence from lake sediments. Journal of Quaternary Science 5:171-87.

Björck S, Håkansson H, Zale R, Karlén W, Jönsson BL. 1991b. A Late Holocene lake sediment sequence from Livingston Island, South Shetland Islands, with palaeoclimatic implications. Antarctic Science 3(1):61-72.

Björck S, Hjort C, Ingólfsson Ó, Skog G. 1991a. Radiocarbon dates from the Antarctic Peninsula regionproblems and potential. Quaternary Proceedings 1:5565.

Björck S, Olsson S, Ellis-Evans C, Håkansson H, Humlum O, de Lirio JM. 1996. Late Holocene palaeoclimatic records from lake sediments on James Ross Island, Antarctica. Palaeogeography, Palaeoclimatology, Palaeoecology 121:195-220.

Doran PT, Berger GW, Lyons WB, Wharton Jr RA, Davisson ML, Southon J, Dibb JE. 1999. Dating Quaternary lacustrine sediments in the McMurdo Dry Valleys, Antarctica. Palaeogeography, Palaeoclimatology, Palaeoecology 147:223-39.

Gordon JE, Harkness DD. 1992. Magnitude and geographic variation of the radiocarbon content in Antarctic marine life: implications for reservoir corrections in radiocarbon dating. Quaternary Science Reviews 11:697-708.

Hall BL, Henderson GM. 2001. Use of uranium-thorium dating to determine past ${ }^{14} \mathrm{C}$ reservoir effects in lakes: examples from Antarctica. Earth and Planetary Science Letters 193:565-77.

Hjort C, Ingólfsson Ó, Möller P, Lirio JM. 1997. Holocene glacial history sea-level changes on James Ross Island, Antarctic Peninsula. Journal of Quaternary Science 12(4):259-73.

Ingólfsson Ó, Hjort C, Björck S, Smith RIL. 1992. Late
Pleistocene and Holocene glacial history of James Ross Island, Antarctic Peninsula. Boreas 21:209-22.

Jones VJ, Hodgson DA, Chepstow-Lusty A. 2000. Palaeolimnological evidence for marked Holocene environmental changes on Signy Island, Antarctica. The Holocene 10(2):43-60.

Levin I, Kromer B. 1997. Twenty years of atmospheric ${ }^{14} \mathrm{CO}_{2}$ observations at Schauinsland Station, Germany. Radiocarbon 39(2):205-18.

Rosqvist GC, Rietti-Shati M, Shemesh A. 1999. Late glacial to middle Holocene climatic record of lacustrine biogenic silica isotopes from a Southern Ocean island. Geology 27:967-70.

Rosqvist G, Schuber P. 2003. Millennial-scale climate changes on South Georgia, Southern Ocean. Quaternary Research 59(3):470-75.

Skidmore MJ. 1972. The geology of South Georgia: 3. Prince Olav Harbour and Stromness Bay areas. British Antarctic Survey Scientific Reports 73:50.

Stuiver M, Denton GH, Hughes TJ, Fastook JL. 1981. History of the marine ice sheet in west Antarctica during the last glaciation, a working hypothesis. In: Denton $\mathrm{GH}$, Hughes $\mathrm{TH}$, editors. The Last Great Ice Sheets. New York: Wiley-Interscience. p 319-436.

Takahashi HA, Wada H, Nakamura T, Miura H. 1999. ${ }^{14} \mathrm{C}$ anomaly of freshwater algae in Antarctic coastal ponds and lakes. Polar Science 12:248-57.

Wasell A, Håkansson H. 1992. Diatom stratigraphy in a lake on Horseshoe Island, Antarctica: a marine-brackish-freshwater transition with comments on the systematics and ecology of the most common diatoms, Diatom Research 7:157-94.

Zale R, Karlén W. 1989. Lake sediment cores from the Antarctic Peninsula and surrounding islands. Geografiska Annaler 71(A):211-20. 